\title{
素 描
}

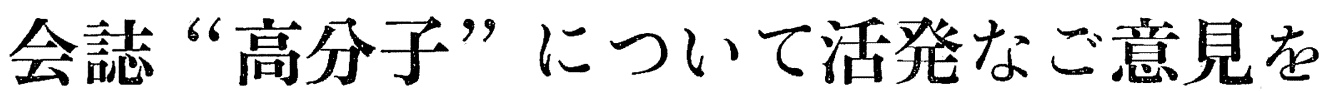

大 野 泰 雄*

高分子学会は戦後急速に発展した学会の一つであります。これは歴代学会長, 荒井常務理事をはじめ, 関 孫役員执よび会員のヴィビッドなご活躍に負うところが大でありますが，また時流に乗った学会であった ことも率直にみとめなければならないと思います。そこでこの時期に学会の主要な使命について，る一

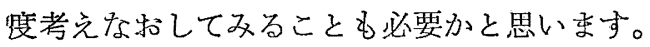

学会はそ矢関係する研究ならびに技術の領域に怙いて，その進歩発展槣与するとともに，会員相互の 向上と親睦をはかることも，その使命の一つでありましょう。

学会が会員に奉仕するためには, 研究, 教育, インホーメーション・センター的活動の三つの主要な活 動が考学られます。

学会が研究発表会を定期的に持ち, 研究誌を発行することは学会として最小限度の研究活動であり, ど の学会も行なっていることであります。第 2 の教育活動は学会に負わされた一つの重要な使命と考充られ ます。多くの学会が研究誌以外に機関誌を発行し, 会員相互の共通の広場として会員へのサービス活動を 行なっているのは，この方面への配虑によるるのと思います。高分子学会がいろいるな研究委員会を持ち， 講習会を開き，あるいは夏季大学を開催するのも学会の持つ教育活動の重要な一面でありましょう(この

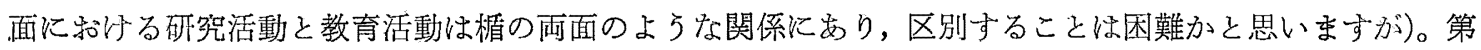
3 のインホーメーション・センター的活動は, 学会が今後力を入れていかなければならない一つの面と考 光られます。高分子学会では, はやくょり海外文献の紹介誌として「海外高分子研究」を発行し，末た会 誌「高分子」にアブストラクト欄を設けているのも，この方面の活動であります。しかて急速に增大した インホーメーションを正確に，しかも迅速に会員にサービスすることは至難なことといわなければなりま 屿え。これらのインホーメーション・センターとしての活動に関する事柄については竹田企画委員長のむ とで種々検討されているやに聞いて括ります。

上述の教育的ならびにインホーメーションのセンター的活動については, 会員相互の共通の広場として の会誌「高分子」の誌上を大い活用すべきものと考皎す。この点に関し会員の皆様の率直なご意見を 物聞かせいただければ幸いに思います。

さて「高分子」の編集委員長を特引き受けして，その責任の大きなことを感じています。しかし委員会 は組織でその仕事を遂行していますので，委員の皆様から忌憚なく発言していたでき，会誌を充実したも のにしてまいりたいと願っています。会誌には会員の皆様が主体的に投稿していただくページをふやして まいりたいと思いますし，また内外の二ニースを随時ご投稿していただくページも新設したいと考えてい ます。会員の皆様が会誌について委員会なり，あるいは事務局編集部に気軽にご意見を和寄せ下さること を期待しています。

さて会誌「高分子」が会員に奉仕する領域も実に広範多岐にわたって物ります。したがって，ある方々 性陽のあたる領域で，山る方々はきわめて地味な領域で研究に，技術の発展にご活躍なさり，ひと乙く高 分子学の発展に寄与されています。高分子」がまたこれらきわめて地味な領域に利いてご活躍の方々を勇 気づけるものであって欲しいと思ってい京す。

さらに広範囲な領域より新しい会員の入会をご勧誘下さることを拈願いします。

\footnotetext{
* 東京農工大学教授・工博, 高分子編集委員長
} 